\title{
Major Themes in Renaissance Utopias
}

\author{
Dr. Ala Eddin Sadeq \\ Zarqa Private University, Jordan \\ E-mail: alaeddin71@yahoo.com \\ Dr. Ibrahim Shalabi \\ $\mathrm{AL}$ - Isra' Private University, Amman, Jordan \\ E-mail: Shalabi61@yahoo.com \\ Shireen Hikmat Alkurdi \\ Al-Balqa' Applied University, Amman, Jordan \\ E-mail: Shireenk2010@yahoo.com
}

Received: February 16, 2011 Accepted: May 6,2011 doi:10.5539/ass.v7n9p131

\begin{abstract}
Utopian themes reflect the spirit of the age which produces them, and echo its problems, ailments and concerns. Ages of helplessness and despair produce myths of wishful thinking and escape, such as, the myths of the Golden Age and the Earthly Paradise. An age of social instability and widespread discontent and frustration begets literary social utopias of social stability and universal contentment, such as, More's Utopia and other Renaissance utopias. An age of steady progress and prosperity inspires utopias of ambitious hopes of perfection as H.G. Well's Men like Gods and William Morris' News from Nowhere. The twentieth century in which change has madly pace and the necessary adjustments have a frustrating slow pace has created either utopias of men like gods or dystopia of men like beasts, such as, Zamyatin's We, and Orwell's Nineteen Eighty Four.

This paper intends to deal with the major themes of the Renaissance utopias which are often called social utopias, such as Thomas More's Utopia (1516), Francois Rabelais' Abbev of Theleme (1534), Thomas Campanella's The City of the Sum (1613-14), Valentine Andrea's Christianopolis (1619), and Francis Bacon's New Atlantis (1623).

Keywords: Utopia, Dystopias, Humanism, Individualism, Social utopias, Naturalism, Renaissance, Reformation

\section{Introduction}

In general, utopian themes centre around three major topics: the means of attaining utopia; the means of maintaining utopia once it is attained; and the political, social, economic and cultural aims which utopia are claimed to have achieved.

Renaissance utopias pay relatively little attention to the first two topics. Most of them claim that utopia has somehow been attained, that it has become an accomplished fact and a going concern. Moreover, it is safe and free from the vicissitudes of change and is enjoying permanent peace, contentment, stability and security. Therefore, this paper shall give a rather short account of how Renaissance utopias are attained and maintained.

The aims achieved by Renaissance utopias occupy a disproportionately large part of their bulk. The story of each one of them is the first and foremost a story of ideas. Plot, action, adventure, characters, and character development are mere stereotyped fiction instruments subordinated to the main interest of the utopian narrative, namely that of expounding the author's utopian ideas. Therefore, the largest part of this paper will be devoted to the delineation, description and exposition of the Renaissance utopias and ideas.

These aims and ideas concern the utopians way of life and their views in relation to nature, human nature, and the organisation and institutions of utopian society.
\end{abstract}




\section{Attaining Utopia}

In the myths of the Golden Age and Earthy Paradise (Note 1) the attainment of the utopia is hardly accounted for. In general, it is usually ascribed to the miraculous benevolence of some supernatural power.

In most Renaissance utopias the attainment of utopia is attributed to a great individual leader like Utopos in More's Utopia or King Salomon in Bacon's New Atlantis. This is somewhat similar to Plato's philosopher-king in The Republic or to a great legislator like lycurgos in Plutarch's Life of Lycurgos.

In the later utopias, utopia is attained through the long historical process inspired and directed by some mysterious principles in the universe, such as, the principle of progress. This is especially the case in evolutionary utopias.

Another group of utopian writings see no way to the attainment of utopia except the violent revolution. Millenarian movements, apocalyptic expectations, and many Marxist or Anarchists movements believe in no efficient way to realize utopia save that of revolutionary violence.

However, the case may be most of the well-known literary utopias or dystopias hurriedly gloss over this point and say next to nothing on the transformation of the real world into a utopian or dystopian world. They pay little attention to the extremely complicated and seemingly unpleasant of transition from the Status quo to the desired utopia. This has been a serious deficiency and significant gap in the literary utopias. Most of the unfavorable descriptions attached to the utopian perfect life pictures, such as their being escapist, impractical and impossible derive from this fault. (Note 2) Some critics believe that the visions of life that changes may bring about are, in fact, far from reality and they create a totally different substitute world.

\section{Maintaining Utopia}

Once utopia is attained, the social utopias present the aims of utopia as accomplished facts. From More's Utopia (1516) down to Edward Bellamy's Looking Backwards (1888), William Morris's News from Nowhere (1891), and H. G. Wells' Men like Gods (1922), the utopian ends and objectives are portrayed as living realities enjoyed by every citizen. It is claimed that these ends are so firmly established that they are taken for granted, and that the utopian society has become a clock - work system functioning almost automatically.

Thomas More $(1949,73)$ claims that the history of Utopia covers over 1760 years from the conquest, and implies that the utopian society there has always enjoyed stability, plenty, contentment and internal peace.

Nevertheless, most writers of the social utopias seem to suspect their claims, and contrive a set of political, economic, social and educational measures which are supposed to close all doors to change and make the permanence of the utopia set up double sure.

\section{The Ends and Aims of Utopia}

The utopian ends of particular age reflect its characteristics ailments and imperfections. They derive from the needs and ills that seem most urgent and prescribe cures that seem most potent on the whole, both the problems and solutions, the ills and the cures, relate to one or more of the following: nature, human nature and society.

\section{Utopianism and Nature}

\subsection{Nature in ancient times}

Nature was the first source of human unhappiness to impose itself on the attention of men. To our ancient ancestors, it seemed and insurmountable obstacle to human survival and security. It was experienced and conceived of as a malevolently destructive presence whose wrath could perhaps be appeased by prayers and offerings, and whose favour might possibly be won by prayers and sacrifices to its gods (Note 3 ). Therefore, the utopian themes of those ancestors reflect their helplessness and despair, and express deeply -felt and frustrated needs for security, plenty and comfort. Their myths for the Golden Age and of Earthly Paradise dramatize a shameless desire for abundant food and drink, for a complete care-free life, and for absolute freedom from all kinds of necessity and limitation. Those utopian myths have nothing realistic, natural or logical about them. They are miraculously plentiful and pleasant, and magically wonderful and happy. In them, all the imperfections of ordinary life are simply banished and ignored.

\subsection{Nature in the Christian Middle Ages}

With the coming Christianity to Europe, European utopianism was hissed out of life as blasphemous. Until the sixteenth century no utopian dream of significance appeared. Mundane and secular interests and ambitions were hushed down. Christianity considered natural hardships as necessary scourges to whip Christians into submission to the will of God. They are the inevitable hell or purgatory on the way to Heaven. Nature now is "postlapsarian", 
a fallen nature which should be subjected to continual correction. It is not the "pretlapsarian", the innocent and happy nature of Eden. After the Fall, Marinelli (1971:20) says:

"Death enters the world of creation and the oneness of man with nature in perfect obedience of the creator is lost...The consequence is exile from the pastoral gardens, exile to a world of toil, labor, and mutility."

In the Christian climate of thought utopianism had no place. For utopianism consists of mundane ambitions, of achieving collective happiness here on earth (Gerber, 1955:7), whereas Christianity asserts that such achievement is utterly impossible except in the Millennium when Christ would come down to earth a second time to destroy Babylon and to establish the kingdom of God around a new Jerusalem (Note 4). Otherwise, the utopian dreams are whispering of the devil who aims at luring men into everlasting damnation and hell.

\subsection{Nature in the Renaissance}

When literary utopias began to appear, especially in the sixteenth century and after, men had already won man the battle against nature. They had become more self-confident, less afraid of natural hostile phenomena, and more ambitious to win ever more battles against them. Step by step, men had disclosed many of the laws of its behaviour, had domesticated nature and harnessed it to the service rather than the destruction of mankind. The first great climax of this human offensive against nature was trumpeted by Francis Bacon who prescribed and advocated effective and systematic methods for conquering nature. Bacon's house of Salomon in New Atlantis, (1623) can be considered the first typical headquarter for a concerted and immensely successful attack to nature.

Not quite scientists himself, Bacon is considered as the father of modern science. The services he rendered to science were not in the form of scientific discoveries and inventions. In such fields, Galileo Galilei, William Gilbert and William Harvey were much better scientists. Bacon's main and lasting service to science is, according to Rene Dubos (1961:30), "To have blown the clarion call which awakened Europeans to the fact that science could completely transform society." According to Morton (1968:83),"Bacon's great service to science was that he gave it an incomparable advertisement".

Bacon's life - long interest was in learning and science. In 1605, he published The Advancement of Learning, a classification and critical survey of all existing knowledge. In 1620, he published his greatest work, the Novum Organum, an exposition of the new experimental method. New Atlantis (1623) was the last of his works.

In The New Atlantis, Bacon is an inventor in a number of ways. To Marie-Louise Berneri (1971:127), "he is the first philosopher to envisage a renovation of society through science". To Rene Dubos (1961:64), Bacon is the first utopian writer who entrusts to science, not to moralists, reformers or politicians, "the problem of making society wise, kind of prosperous." Bacon was also one of the first philosophers to recognize that science meant knowledge and knowledge power. Therefore, this in The New Atlantis is surrounded by secrecy similar to the secrecy which surrounds scientific inventions in our modern times. Benrneri (1971:132) claims that:

"The scientists of Bensalem set as spies on behalf of their college, and though they drain the world of all its new inventions and ideas, they give nothing in exchange."

Bacon was also the first to discern that for science, to be effective in mastering nature, it should be collectively disciplined and organized into a systematic body of operations applicable to all problems. According to Dubos (1961:28),

"he (Bacon) depicted in .... The New Atlantis a utopian society guided by a community of scholars who devoted themselves to scientific research, to the organization of knowledge, and to the pursuit of wisdom. In the words of their leader, 'The end of our foundation is knowledge of causes and secret motions of things; and the enlarging of the bounds of human empire, to the effecting of all things possible."

Bacon has alone had this privilege among utopian writers: his proposals concerning the formation of a community of scholars and scientists were put into action. The English College of Philosophy (1645) which developed into Royal Society (1662) was carrying into effect of Bacon's outline of Salomon's House (Morton, 1968:1986). The French Academy of Sciences, created by Colbert in 1971 was another scientific institution founded to put in practice the concepts of Bacon. The French Encyclopedists acknowledge their intellectual indebtedness to Descartes, Newton, and Locke, and especially to Bacon. Dubos (1961:37) quotes the editors of The Encyclopedia compiled by the Encyclopedists, as saying:

"At the head of these illustrious Heroes we deservedly place the immortal Francis Bacon ..... we are tempted to esteem him the greatest, the most universal and most eloquent of all philosophers ...." 
Dubos (1961:35) also states that:

"Only during recent decades has Bacon's vision come even closer to reality in the form of academies of the U.S.S.R. and their scientific institutes."

Bacon has thus convinced the world at large to recognize and use scientific knowledge and technology as an instrument of power. This, undoubtedly, has led to increase of man's dominations over nature, but, undoubtedly as well, it has not increased man's happiness.

The scientific ventures, since Bacon, have produced such celebrated scientists as William Harvey, Galileo, Descartes, Newton, Faraday, Louis Pastor, Charles Darwin, Thomas Edison and hundreds of other who contributed to man's conquest of nature and to the enthroning of the human race as its king and master.

The theme of nature in utopian literature has thus developed from one of despair and escape to a theme of unbounded hope and unlimited conquest. Myths of the Golden Age have left the stage for realistic utopias of great expectations. Richard Gerber (1955:143-160) lists around sixty utopias and dystopias produced between 1901 and 1950, based on the scientific conquest of nature. The utopias express absolute confidence in the efficacy of science to control and guide the behavior of nature. The dystopias betray the fear that man has over-reached himself, and that science has made men more powerful than wise. In Wikipedia, it is mentioned that " Scientific and technological utopias are set in the future, when it is believed that advanced science and technology will allow utopian living standards; for example, the absence of death and suffering; changes in human nature and the human condition. Technology has affected the way humans have lived to such an extent that normal functions, like sleep, eating or even reproduction, have been replaced by artificial means."

Berneri's conclusion (1971:137) on Bacon's contribution is a convenient conclusion here:

"The New Atlantis can have little attractions for us, since we are living in Salomon's House today and, like Bacon, we have been dazzled by the riches and marvels it contains. We are gradually realizing that knowledge and scientific progress are not synonymous with human happiness, and we begin to suspect that the enthusiastic supporters of progress were not really concerned with happiness of man kind but with the power that this knowledge and progress gave them .... We are also in a better position to appreciate the dangers of 'science without conscience'. The thought that the harnessing of atomic energy may spell the end of our civilization has deprived science of its glamorous halo. The scientist is no longer considered as a benefactor of humanity, but unwillingly assumes a sinister role and is himself sometimes overcome by feelings of guilt."

\section{Utopianism and Human Nature}

\subsection{Man is inherently evil}

In the middle ages, Europe, especially North Europe was permanently harassed with scarcity, bitter cold, plagues, invasions, and wars. With the fall of Rome and the loss of order in Europe, miseries increased. Christianity and the Church seemed the only refuge, for they gave loquacious promises of an eternal life of bliss, comfort and warmth to be won after a transitory, short and tortuous life.

The Catholic Church stressed that man in earth is inherently evil, a sinner that he is in a fallen state; that he must face to the end the consequences of the Fall which his parents, Adam and Eve, he started. Man had once enjoyed a paradisal existence, but he has forfeited it all through his sinful pride and his disobedience to his Father, God. A return to Eden would be granted to man if he successfully passes a series of trials. Dante's Devine Comedy (1308-1320) and Bunyan's The Pilgrim's Progress (1678) give the best dramatic pictures of such trials. On the way to heaven, man shall face pain, misery, torture, false attractions of material comforts, false beauty, false power and wealth, all sorts of attractive error, and if ever he is snared by any of them, his final prize (heaven) is forever lost.

The major theme of Christianity is reunion with God and regaining Paradise. This can only be achieved through the redemption and salvation of the soul, the renunciation of the body, and the denial and abandonment of selfhood. But the important point of our purpose is that the return to Eden is not communal; it is not to be attained by collective effort for the benefit of all. To Marinelli (1971:19), "Christianity promises no such general renewal; the Edens that can be created are those of individual soul, the paradise within."

Social perversity is the result and not the cause of man's pride and error. After all, society is not society of saints, but rather a society of fallen evil men. Their inherent sins of pride, greed, gluttony, sloth and lechery are reflected in their social behavior and breed common misery. Reforming society was therefore considered futile because the bricks that made society were deemed rotten. 
It is in the words of Gerber (1955:7):

$" \ldots$ the religious and the utopian views cannot be entirely reconciled: if this life is essentially sinful and imperfect, what is the good of bettering conditions? The endeavor is futile" (Note 5)

Near the end of The Middle Ages many new and revolutionary aspects of human life were being born. They were annoyingly felt but not fully understood. The feudal and agrarian system was disintegrating and being replaced by a mercantile and capitalistic system. International trade was thriving and expanding and so were the cultural exchanges, especially with the Muslim in the South and the East. (Note 6) Translations of the Bible into the vernacular languages of Europe were being made. Greek and Roman classical heritage was being discovered and appreciated. Big cities were rising. National awareness and powerful central national governments were taking shape. New scientific and geographical facts were being discovered. These and many other momentous changes were taking place, and with them man's outlook on life and human nature was being renewed along new lines. The lists of these changes are historically classified under three headings: The Renaissance, Humanism, and the Reformation.

\subsection{Man is inherently good and innocent}

Under these changes the European mind developed new attitudes to life and human nature, and embraced a new conception of history. T.E. Hulme (1924) states: "You get at time the appearance of a new attitude which can most broadly be described as an attitude of acceptance, as opposed of to an attitude of renunciation."

Political, social and economic relations were re-arranged. Pessimism was replaced by optimism. The dogma of Original Sin was ignored, if not discarded. Man was viewed as an innocent victim rather than a sinning trouble-maker. The conviction that Satan is the lord of this world was disfavored by a rising conviction that man should be its master. Basil Willey (1934:33) classifies this issue "as prosperity and stability of civilization gradually increased, and .... as life became more secure man become less otherworldly."

\section{Utopianism and Society}

\subsection{Utopias in societies}

K.R. Popper (1974) suggests that literary utopias came into being with the rise of civilized big cities or what he calls the open society, and the breakdown of the harmonious and warm tribal society or what he calls the closed society.

Civilized city life granted men many blessings but it plagued them with many discomforts such as:

1. The rapid pace of change which required continues adjustments and created a greet deal of strain. The utopians dreamed of social stability in which change would be stopped or reduced to a happy minimum.

2. The dazzling and limitless variety and the bewildered disunity which necessitated endless adaptational efforts. The utopians tried to relieve this situation by calling for unity and conformity.

3. The absence of recognized and permanently respected patterns of behavior and conduct. This gave life a disorderly and chaotic aspect and bred neurosis, anxiety, restlessness and fear. The utopians aimed at giving this missing order and pattern of conduct, and at removing the neurosis by giving the order and the pattern permanent sanctity.

4. The dominance of a keen, cruel and unprincipled competition for the material comforts in a world where individuals have lost the tribal solidarity and became rootless. This led to a widespread felling of insecurity, which destabilized the psychological balance of most men. The utopians, therefore, therefore, endeavored to restore this lost psychological balance by barring economic competition and ensuring in abundance and for every utopian citizen all the necessities of life such as food, drink, clothing and shelter, together with a reasonable degree of comfort and release from drudgery.

With the advent of Renaissance humanism and the rise of the open society, utopianism gathered new force and its voice became audible. There was a huge output of utopian pastoral poetry such as The Shepherd's Calendar by Edmund Spenser (1579). In addition to pastoral poetry, there was a rich outpouring of utopias proper which are quoted in most books dealing with utopianism. (Note 7) The best-known Renaissance utopias are Thomas More's Utopia (1516), Thomas Companella's The City of the Sun (1613-14), Valentin Andreae's Christianopolis (1619), Francois Rabellais' The Abbey of Theleme (1534)

These Renaissance utopias emphasize the social aspects of the human dilemma. Nature and man recede in the background, and the assumption that a good organization of human and social affairs would make men happy dominates men's mind. The sources of the social ills that seem to have occupied men's mind can be summed up 
under the following headings:

1. The individual and the state.

2. Property and money.

3. Family life and sex activities.

4. Labour and leisure.

5. Religion.

6. Education and science.

\subsection{The Individual and the State}

The Renaissance utopias seem to have some reservation about the Christian tenet that man is originally sinful and the human misery stems from the evil inherent in him. They see the roots of evil in the social set up, and propose to dig those evil roots and to destroy them through re-arranging society on new lines. Rabelais' Abbev of Theleme, for instance, reflects the extreme individualism of Renaissance humanism. The men and women here are liberated from all restrictions, social, religious or otherwise. According to Armytage (1968:16), they are allowed "to do what pleases God, but what pleases them." Like their creator, the Thelemites are typical representatives of the Renaissance. They are highly educated and widely informed. They admire the classics and hate scholastic doctrines. They despise monastic life and monastic asceticism and show unbounded love for freedom and beauty The Abbev of Theleme is, in Berneri's view (1971:138): "the utopia of the new aristocracy of the Renaissance, an aristocracy based on intelligence and knowledge rather than on power and wealth"

More's Utopia, on the other hand, opposes extreme individualism, and binds it with a strict but reasonable order. The citizens of More's Utopia are not allowed to do what pleases them, but what reason dictates. Yet, More believes that the dictates of reason must be pleasant. The citizens of his utopia "define virtue as living according to nature .... They conclude that nature herself prescribes a life of joy as the goal of life" (More, 1949:48). They disassociate themselves from the traditional Christian inhibiting principles, and according to More (1949:48 and 53), they "disagree with the grim and gloomy advocate of virtue, who hates pleasures and exhorts us to toils vigils and squalid self denial." They also "..think it madness for a man to mar his body, to weaken his strength... to wear himself down with fasts ..... And spurn natural delights."

Yet, most Renaissance utopians, except Rabelais, do not have full confidence in the common individual. The happiness and social felicity achieved in their utopians are the result of efficient planning rather than of individual goodness. More offers the citizens of his utopia good "order", but little freedom. He keeps the social eye on the alert to prevent "wanton License of word and behavior." Morton (1968:62-3) explains this in terms of class conflict, and considers More as a representative of the rising middle class, who "shared much of its outlook in spite of his genuine concern for the sufferings of the people." As a middle class man, More, according to Morton (1968:63), "was therefore a man of order' who dislikes nothing more than the independent action of the people. All for the people but nothing by people was his catchword."

Andreae and Campanella have same mistrust of the common individual. The reason in our opinion is two-fold:

First and most important is the fact that these utopian humanists had an ambivalent attitude toward man. They perhaps give unconscious support to the Christian dogma that man is inherently evil, and at the same time give half-hearted support to the new concept that man is originally good. This ambivalence is most clear in the case of Andrea. Berneri (1971:107) who stresses that

"Throughout his (Andrea's) utopia one feels that his love of men inclined him to trust them as sensible beings capable of going about their lives in a reliable and honest way , but his religion told him that man is wicked and has to be carefully guided, preaching to, and if necessary threatened to be kept away from sin."

The second reason is that More and his fellow utopists are the product of the Renaissance and reflect some of its contradictions. The Renaissance bred encouraged individualism, but according to Berneri (1971:56)

"The development of the individuality had taken place in a minority at the expense of the majority .... In the political sphere the initiative also passed from people to a few individuals .... The Renaissance which had allowed the development of the individual also created the state which became the negation of the individual."

This contradiction appears in most of the Renaissance utopias which oppose individualism in their citizens, although many of them are realized only through efforts of heroic individuals. More's Utopia is created by the 
benevolent king Utopos and carries his name, and King Salomon gives New Atlantis and its capital 'Bensalem' their fundamental laws. Thus, most Renaissance utopias prescribe a strong government, monarchical, constitutional or republican. This was in agreement with the spirit of the age in which the feudal life was disintegrated, and peace and security were always threatened.

The most important feature of the state is that it is coercive. This quality is based on the assumption that the social units, in their individual condition, are self- seeking and destructive of the common good. These individual social units, left to themselves, contribute to the disintegration of the social body. It becomes necessary, therefore, for some members of society to govern others for the common good. The most extreme case of such reasoning is to found in Hobbes' Leviathan (1651).

The concept of the state looms large in most literary utopias. In many of them the state is a mean of attaining utopia and of maintaining it. In Plato's Republic, in More Utopia and in Bacon's New Atlantis, utopia is designed and created by individual rulers, benevolent tyrants whose words and deeds become sacred laws. On the other hand, though the political system of each of these utopias is initiated and, for a time, maintained by a tyrant, it does not continue to be headed by tyrants. It becomes a clock-work system, functioning almost automatically. Once Plato's Republic becomes a going concern, its philosopher-king and his assistants are elected through and extensive, selective, and highly demanding educational system. The same is true of Campanella's The City of the Sun whose head of state, the $\mathrm{O}$, and his three assistants are selected through a rigorous and extensive educational process. According to Berneri (1971:100), the O has to be so widely informed and so highly educated that it might seem impossible to find such a man.

"No one can become $\mathrm{O}$ if he does not know the histories of the peoples, their rites, sacrifices and laws; ... all the mechanical arts, ... all the sciences, mathematics, physics and astrology ..... The $\mathrm{O}$ should be a good metaphysician and theologian .... Should be well acquainted with the origin and demonstration of every art and science, .... He must know the species of being and their relation to celestial, earthly and marine things. He must make careful study of the Prophets and Astrologers."

The electing of the governing bodies on the basis of their born talents and academic qualifications is a tradition that was started and popularized by Plato. Thomas More established a somewhat different tradition. Though Utopia is founded by Utopos, an invader and conqueror, it is maintained by a democratic political system. The prince is elected by secret ballot and "remains in office for life, unless he's suspected of wanting to establish a dictatorship" (More, 1949:74). The members of the ruling councils are elected for one year. The whole adult population participates in the elections.

Another characteristic of More's Utopia is that the prince and the state officials are not legislators but mere administrators of the laws that were created long ago by king Utopos. These laws have crystallized into a solid and efficient institution, a body of rules and principles surrounded by a halo of sanctity, practicality and naturalness. Any serious change or serious violation of the laws by the state officials is simply inconceivable. More (1949:73) states that the history of Utopia covers 1760 years from the conquest, and that the society of Utopia has always enjoyed stability, plenty, contentment and internal peace.

More's democratic government was copied, with some variations, of course, by most utopians in the following centuries, particularly the seventeenth century. The English utopias of this century emphasize the essential necessity of a strong and capable government. Samuel Hartlib's Macaria (1641), Samuel Gott's Nova Solyma (1648), Thomas Hobbes' Leviathan (1651), and James Harrington's Oceana (1656), all revolve around the best possible political system. All, except Hobbes' Leviathan, advocate a constitutional monarchy. Like More's Utopia, they bind the monarchial ruler by constitutional laws. These utopias imply the awareness that absolute authority and power may have a corruptive influence on rulers and may lure them into becoming tyrants. Therefore, these utopias established precautionary measures against the rise of such a condition. The first step towards bracketing the authority of the ruler is to give the law a higher value than the king. Harrington (1656:100) says that the government "should be the Empire of the laws, and not of Men." The state in these utopias is the executor of the law, not its maker. The state is as much bound by the dictates of the law as ordinary citizens are.

More's Utopia has no legislators. But the seventeenth century utopias have legislators elected by the people at regular intervals. The laws in More's Utopia are not subject to serious changes, whereas the legislators in the seventeenth century utopias can make new laws or repeal old ones in response to the changes which may arise in the economic, social or political conditions. (Note 8) 


\subsection{Property and money}

Private property and the use of money received great attention in Renaissance utopias. They were seen to be two of the primary sources of human inequality and misery. Property and money mean power and authority, and are, therefore, corruptive. Consequently, More abolishes private property and the use of money. He (1949:19-80) suggests that: "In Utopia where everything belongs to everybody, they know that if the public warehouses and granaries are full, no one will lack anything for his personal use."

Moreover, he (1949:81) adds that "Everyone knows that frauds, thefts, quarrels, contentions, uprisings, murders, betrayals, and poisonings .... would wither away if money were eradicated. Fear, anxiety, worry, care, toil and sleepless nights would disappear at the same time as money. Even poverty .... would vanish if money were gone."

Campanella's The City of Sun also "abolishes property, not for one class only, but for the whole community." Berneri (1971:98) quotes Campanella's as saying:

"All things are in common and are administered by the magistrates. Not only food, but knowledge, honours and pleasures are common, in such a manner that no one can appropriate anything for himself."

Renaissance Utopias handling of the economic theme echoes the classical view (Plato's The Republic and Plutarch's Life of Lycurgos) that economic concerns have demoralizing effects on the political set up and on the social relations. With the exception of Bacon's New Atlantis, all Renaissance utopias abolish private property of land and prohibit the use of money. More, Campanella and Andrea advocate frugality and austerity and eliminate internal trade. They build egalitarian societies in which all citizens are made to work and all works and all works are, economically, equally rewarded. Nobody is allowed to remain idle and nobody sleeps hungry. All essential economic needs are ensured, but no luxuries are allowed to exist, for indulgence of the flesh was believable to corrupt the mind. On the whole, economic activities and relations in Renaissance utopias had no corruptive influence, either in the political or social arrangements.

\subsection{Family life and sex activities}

These subjects receive different treatment from different authors. More, Bacon and Andreae call for keeping the family as an important social unit. More, however, allows the would-be bride and bridegroom to see each other in the nude before deciding to marry, to make sure that none of them has hidden deformities. Campanella, though a staunch Catholic, abolishes the family and allows extramarital sex. His only concern is producing a healthy race. According to Berneri's (1971:100-101)

"The laws of the City of the Sun concerning sexual relationships are solely dictated by the concern to produce a healthy race. Campanella is more thorough in his eugenic theories .... It is rather startling to see how little Campanella's conforms to the Orthodox Christian morality which condemns all sexually unions whose purpose is not that of reproduction, and all the idea that sexually repression in young people is harmful and must be avoided strikes one as very modern."

\subsection{Labor and leisure}

Unlike Plato and the classical utopias, and unlike the myth of the Earthly Paradise, the Renaissance utopias give labour, mental as well as physical dignity. They recognize it as a natural necessity and make it a duty for all citizens. In More's Utopia (1949:33-35):

"All the Utopians ... work at agriculture, and no one is inexperienced in it ... Besides sharing in the farm work, every person has a particular trade of his own. The Utopians work six hours of twenty-four.. And sleep eight hours."

In Andreae's Christianopolis, according to Berneri (1971:112), work occupies and honoured position. Andreae condemns the prejudice against manual labour and reconsiders this issue by emphasizing the significance of this type of labour. He clarifies:

"There are also public duties, to which all citizens have obligation, such as watching, guarding, harvesting of grain and wine, working roads, erecting buildings, draining ground, also certain duties of assisting in factories which are imposed on all in turn .. For what we are in our homes, they are in their city, which they not undeservedly think a home. And for this reason it is no disgrace to perform any public function ... With an entirely mistaken sense of delicacy do the carnal-minded shrink from touching earth, water, stones, coal and things of that sort."

Since work is a duty and is made a pleasant one by shortening work hours, and since no citizen shirks his duty, slavery is no longer needed. On this and other moral grounds the institution of slavery is abolished in most 
Renaissance utopias. More, however, keeps slaves in his utopia, but he does not call them slaves. Instead he uses the term "bondmen." These are either war captives or law-breakers. More (1449:56) says: "their bondmen are either their own citizens who have been sentenced to bondage for some crime, or men of other nations, who have been condemned to death."

The bondmen also include servants or what is now called "hired labourers". More (1949:57) gives the following description of them:

"Another class of bondmen consists of poor hardworking menials of some other nation, who have chosen of their own accord to come and serve the Utopians. They are treated well.... if they wish to leave they are not detained... nor are they sent away empty-handed."

\subsection{Religion}

In most Renaissance utopias religion is not clearly defined nor does it receive detailed and emphatic treatment. In general, most monotheism is dominant. Religious dogma, practice and worship are founded on reason rather on revelation. Religious toleration is favoured and religious schism is frowned upon.

On the whole, Renaissance utopian attitude towards religion is the traditional Christian attitude but partially adjusted to suit utopian purposes such as stability, order, contentment and peace. No emphasis is given to the myth of the Fall and to the concept of the Original Sin. The concept of the 'trinity' is gradually replaced by Unitarianism. Religious toleration replaces fanaticism.

\subsection{Education}

Education is highly emphasized in Renaissance utopias, for it was through education that good utopian citizens were to be made, and good utopian rulers were to be created.

Thomas More does not describe educational programs or institutions, but as one reads through his Utopia, one feels that its citizens are well-educated people.

Campanella and Andreae give special attention to education and offer detailed descriptions of educational programs and institutions. Berneri (1971:99) tells us that in Campanella's The City of the Sun, children start learning when they are three year-old, as they learn alphabets and language. When they are seven, children start to have their own likes and dislikes about trades. After studying natural sciences and then mathematics, medicine or other courses, they start to choose their preferable field, in which they find themselves.

The O, or the head of the state in The City of the Sun has to be widely informed and very highly educated.

The most elaborate and best rationalized description of the educational system and institutions is given Andreae's Christianopolis. Education here is for all citizens, boys and girls and not for "a small privileged minority, the sons of princes and rich merchants ... for this reason his education has none of the glamour of that received by the fortunate Thelemites, but it has the advantage of being accessible to all." Berneri (1971:118).

After their sixth year the children are given over to the state which lodges them at schools, gives them good education and nutrition food and surrounds them with hygienic conditions.

Great care is given to the school buildings, which are made roomy, sunny, attractive fully supplied with means for fruitful education and "honourable" recreations.

Similar great care is given to the choice of masters and matrons. In the word of Berneri (1971:119),

"Their instructors are not men from the dregs of human society nor such as are useless for other occupations, but the choice of all the citizens, persons whose standing in the republic is known and who ... have access to the highest position in the state."

The school is divided into eight classes "which correspond to the eight departments of education." The subject taught form a formidable list and include three languages (Hebrew, Greek and Latin ), oratory, logic, metaphysics, theosophy, arithmetic, geometry, algebra, music, astronomy and astrology, natural philosophy, secular and church history, ethics and finally theology. (Berneri, 1971:122-123).

In addition to this highly ambitious educational program Andreae, according to Berneri (1971:123),

"was interested in the formation of a 'college' or society which would unite all men of learning and provide them with the necessary means to carry out their researches. His ideas concerning this 'college' influenced those writers and philosophers who laid the foundations of the Royal Society in London. It is probable also that Bacon was acquainted with Andreae's works that they influenced his invention of the House of Salomon" 


\section{Conclusion}

Thus, Utopia is an ideal place where people enjoy a socially, politically, legally perfect organism. While some of these Utopias are goals that communities try to attain, others are fictional worlds described in literature. Whether Utopias deal with religious, social, scientific, economic aspects, they all search for societies far from evil regardless of its different standards or methods. Through revolution or evolution perfection has been working as a magnificent target for human beings over the decades.

\section{References}

Al-Direeni, Moh'd Raja. (1989). Utopianism Outside Literary Utopias. Arab Journal For The Humanities, Vol. II, 7.

Armytage, W.H.G. (1968). Yesterday Tommorows: A Historical survey of Future Societies. London: Routledgr \& Kegam Paul.

Berneri, Marie-Louise. (1971). Journey Through Utopia. New York: Shocken Books.

Chew, Samuel G. (1965). The Crescent and the Rose. New York.

Cohn, Norman. (1957). The Pursuit Of the Millennium. London: Secker and Warburg.

Dubos, Rene. (1961). The Dreams of Reason: Science and Utopias. New York: Columbia Univ. Press.

Elliot, Robert C. (1970). The Shape of Utopia: Studies in a Literary Genre. Chicago Univ. Press.

Gerber, Richard. (1955). Utopian Fantasy: A study of English Utopian Fiction Since the $19^{\text {th }}$ century. London: Routledge \& Kegan Paul.

Hamilton, Edith. (1969). Mythology, Timeless Tales of Gods and heroes. New York: Mentor Books.

Hertzler, Joyce Oramel. (1965). The History of Utopian Thought. New York: Copper Square Publishers.

Hitti, Philip. (1970). History of the Arabs. London: Macmillan.

Kateb, George. (1963). Utopia and its Enemies. New York: Collier-Macmillan.

Manuel, Frank E. (ed.) (1971). Utopian Thought. London: Souvenir Press.

Molnar, Thomas. (1972). Utopia, The Perennial Heresy. London: Tom Stacey.

Morton, A.L. (1968). The English Utopia. Berlin: The Seven Seas Publishers.

Popper, K.R. (1974). The Open Society and its Enemies. London: Routledge \& Kegan Paul.

Utopia. / Utopia - Wikipedia, the free encyclopedia.

\section{Notes}

Note 1. For further information on the myth of the Golden Age, see.

- Moh'd Raja Al-Direeni, "Utopianism Outside Literary Utopias", Arab Journal for the Humanities: vol.2, No.7 (summer 1982), pp.275-294.

- W.H.G Armytage, Yesterdays Tomorrows (London :Routledge \& Kegan Paul, 1968),p.6

- J.O. Hertzler, The History of Utopian Thought (New York, Cooper Square Publishers, 1965), P.99

- Hesiod, "Works and Days" in Hesiod, trans. by R.Latimore (Ann Arbor, Univ. Of Michigan Press, 1959), PP.31-32

- P.V Marinelli, Pastoral (The Critical Idiom, No.15), (London: Methuen co., 1971), P.15.

For more Information on the myth of the Earthly Paradise, see:

- $\quad$ Al-direeni, "Utopianism outside Literary Utopias", p.280.

- Richard Gerber, Utopian Fantasy (London: Routledge \& Kegan Paul, 1955), P.364.

- A.L. Morton, The English Utopia (Berlin: The Seven Seas Publisher, 1968), P.16.

- G.Negley and J.M Patrik (eds.) The Quest for Utopia (New York: Garden City, 1960), P.235

Note 2. For a more detailed discussion of the problems of attaining and maintaining utopia see George Kateb, Utopia and Its Enemies (New York: the Free Press of Glenco, Collier- Macmillian, 1963).

Note 3. For more information on the Gods of Nature who believed to control human behaviour see: 
- Edith Hamilton, Mythology: Timeless Tales of Gods and Heroes (New York: mentor Books, 1969).

Note 4. The various expressions of the concept of the Millennium are detailed in Norman Cohn's The Pursuit of the Millennium (London: Secker and Warburg, 1957).

Note 5. See also Thomas Molnar, Utopia: The Perennial Heresy (London: Tom Stacey, 1972)

Note 6. For Further information on this point see

- $\quad$ Philip Hitti, History Of the Arabs (London: Macmillan, 1970)

- Samuel G. Chew, The Crescent and the Rose (New York, 1965)

Note 7. Examples of such books are

- A.L. Morton's The English Utopia (1968)

- Marie-Louise Berneri's, Journey Through Utopia (1971)

- Frank E. Manuel (ed.) Utopias and Utopian Thought (1971)

- Thomas Molnar, Utopia, The Perennial Heresy(1972)

Note 8. Further development in the relations of the State and individuals as reflected in the utopian literature of the following centuries will be dealt with another paper. 